\title{
Media Market as an Example of a Deregulated Market: Historical and Social Analysis of the Local Media
}

\author{
Jarosław Kinal ${ }^{1}$
}

\begin{abstract}
The media market consists of: media (media, ie television, radio and printed press, as well as new media in the domain), their recipcom and filter, and so-called. regulators, that is organizations and institutions that control media activities (note: Internet content is not a regulation format). The National Council of Radio Broadcasting and Television controls the content of television broadcasting and analyzing programs as well as receiving and receiving concessions. The Office of Electronic Communications assigns and controls the subject of technical possibilities of broadcasting radio and television programs. Citizens' organizations that oversee media activities. These include industry organizations, e.g. journalistic associations. The media are businesses. To the fact that in their activity they are guided not only by interest, openness or mission, but also by financial profit. There are three basic ways to fund the media. Public media owned by the public is financed from the subscription and advertising. The money from the subscription is spent on the socalled mission, advertising revenue - for other purposes (eg entertainment programs). Commercial media is financed from private capital and advertising. Social media (do not mistake them for social networking sites). Setting up and running a television or radio station for a very expensive investment. The media market 1 is available only to you. To, that the value of the collection program along with its popularity. Therefore, more people watched the video, the more you have to pay for advertising during this broadcast. To make as much money as possible, senders need to care about the attractiveness of the program. To do it in various ways, e.g. to decide to profile the program. Universal programs are suitable for various types of programs: entertainment, educational, information etc. Thematic programs such as: culture, sport or motorization.
\end{abstract}

Keywords: media, labor market, local media, Poland, open market

\section{Introduction}

The media system has been the subject of market discussion since the 18 th century. The history of the emergence and development of mass communication and mass media, channels of its adjustment to recipients shows that one of the most important factors affecting them was not the economic element. He influenced the definition of their goals and tasks, facilitated the formation of related structures. The significance of this factor will become clear when the place and role of mass communication in the entire economic system is clarified. Its role as one of the elements of this system is determined by the fact that mass communication is also a variant of production manufacturing activity. (Corner 2007) If we come out of such a conception of mass communication as a special kind of production activity, we should show all the elements of the creation process by its nature. He has an objective, as every activity, that the manufacturer seeks. The latter uses the means of production by means of which he develops (processes) the manufactured object. However, the whole thing is a change in intellectual, spiritual production. It differs significantly from industrial activity. (Webster, 
2002). These differences are characteristic of the whole sphere of mass communication. The journalist producer also uses specific means of production. The journalists' working tools used in this field are only characteristic of it, and the same applies to the use of methods, methods, techniques and working habits. Also the object of journalists' influence is specific - it is primarily social information. Everything that concerns human life, which is of interest to people received from various sources. All the more specific is the production of this activity. Journalistic information because not all social information becomes journalistic information. It presents social information in a special way designed to quickly provide it to those in need to facilitate their adoption and influence on them. (McChesney 2012) These studies are made in the media editorial offices. From where it is directed to readers, viewers or radio listeners. The information journal has a dual nature, on the one hand, the intellectual product of the activity produced in order to influence the human consciousness, leads it to a specific activity. (Capurro, R., Hjørland, B. 2003) Changes in his perception of the world and better orientation in the life situations he finds himself in. On the other hand, the information diary comes out on the market and be comes a commodity. Like any commodity, it has utility value and simply value. The first means the ability of this product to meet the information needs of the recipient. The second is the price of the effort necessary to produce this product. Various types of mass information provide the market with various varieties of this product, which is journalistic information. Television and radio continuously and systematically produces the latest information. Newspapers are unable to compete with them in the development and continuity of delivering new messages. Therefore, it gives its recipients primarily commented information. (Kovatch, Rosenthal 2007)

Magazines produce their special production of specialized analytical information and present their readers with the results of journalistic and artistic images of reality. Informative needs arising in people force them to look for carriers of the information they need and purchase it. In this way, market relations between the producers of journalistic information and those in need arise. This starts the process of exchanging between them during which both sides meet their needs. Who needs information, he buys it in the form of a message, knowledge or opinion. They help him to orientate himself in the surrounding reality. The journalistic information producer also meets their needs. By selling his goods, he receives not only financial means in the form of remuneration, he also receives compensation, and in the second form, the possibilities of intellectual ideological influencing the readers of radio listeners or television viewers. (Rodgers 1976) Another form of compensation for a journalist's work is possible as a result of this market exchange. He gained publicity as the author of recognition of his professionalism. Together with the financial journalist, the compensation is also paid to the publisher and owner of the mass media. Just like any journalistic product, information appears on the market in a specific form of unity. This unity takes on various forms and forms. Most often it is the entire issue of a newspaper or magazine that is bought by a potential reader. It may, however, be a future publication that will go to the next issues, articles, reportages, original photos that the editorial office can buy. On television and radio, the unity of goods occurs in the form of the entire program or separate themes or threads. In turn, an information or press agency proposes its production on the market also in the form of its trade unions, newsletters, trailers and 
photo services. However, in any case, this market launch should be finished with a purposeful, conscious product, production having its utility value. Therefore, many activities on the media market are preceded by detailed research. Openness of the media market includes not only economic issues but also social and ethical aspects. In particular, this process is visible on the example of the local media market. (Shangyuan et al 2018)

\section{Social Problems of Local Media}

To the social problems of local media the author has addressed the related problems with the reception of the medium in the local environment. As mentioned above, the problem of public confidence in the local journalist is a significant problem. The analysis of 150 Internet users' posts under 18 articles posted on local portals: nowiny24.pl, supernowosci24.pl and rzeszow.gazeta.pl points to a significant problem connected with the acceptance of the journalist by the audience and a considerable misunderstanding of the specifics of the profession. Among the comments most entries referred to the reliability of the journalist's article, in the vast majority $(76 \%)$ these were critical posts. Another critical element, in the opinion of Internet users, was the selection of experts who spoke in the content of the article made by the journalist. Most Internet users denied competence (47\%), speech style (21\%), and criticized past and expert experience (13\%). This problem only concerns local press. On the pages of local radio stations for information not aobserwowano such entries. This may indicate a different profile of the recipient of the type of media and the level of competence of the media type. As Sylwia Męcfal points out, "it can be expected that in press centers where the local press is particularly important and highly popular, it will be very difficult for a journalist to do the work of a journalist." (Męcfał 2011:129) Another important, from the point of view of local media, is the social acceptance of the medium in selected areas. Exemplification of this problem can be accommodating to the local press in particular districts in the group of football fans. The analysis of the contents of the internet forums shows the attitude of football fans to the medium, eg when Gazeta Codzienna Nowiny reported the construction of the stadium at the "Stal" City Stadium in Rzeszow, the supporters of the opposing team, Resovia Rzeszów, in their fora signaled the need to boycott the newspaper " "There is no data on the sales of newspapers in selected regions dominated by supporters of a given team, but the aspect of trust in a given title by a selected social group in relation to the media coverage of an event may synerify the potential research problem.

\section{Ethical Problems of Local Media}

Among the potential problems of local media, the author of this paper has distinguished problems connected with external censorship, self-censorship and internal censorship. Sylwia Męcfał defines these phenomena, by S. Mock follows: "Selfcensorship is a situation where the journalist himself take dec s eat to something In the material do not disclose, something silent, mainly because of the good informers or heroes described in the material, but also because of the awareness that certain content is 
not well seen in the editorial. Internal censorship is one which exists within the editor, for example. Certain subjects are prohibited other in col EI prefers not treated. Censorship is anykind of external pressure on the effective re dakcję that the material did not appear, or the situation in the Po land before 1989, when all the heavy media materials were controlled and censored by the censor institution" (Męcfał 2011: 125)

Among local journalists in the Rzeszów environment, no research has yet been conducted on the occurrence or absence of this type of phenomenon. Katarzyna Pokorna-Ignatowicz notes, however, the possibility of political pressure on editorial boards or lack of certain content. Pressure may be the promises of advertising orders by individuals and organizations governed by political representatives or advertising material ordered during election campaigns by election committees. (Pokorna-Ignatowicz 2001) An important aspect of ethical journalist is also a realization of the assumptions of the Act of 01.26.1984 - Law Pr aces, one of which records Article. \10 \2. obliges the journalist "within the framework of the employment relationship is obliged to implement in the statute or regulation of the editorial office in which he is employed, the general program line of this editorial" (Polish Press Law, 1984). It also saw the involvement of one local newspaper title in the local election campaign in 2010. During the electoral campaign in local elections, there was a local election committee where most of the candidates were journalists of one of the titles. Sylwia Męcfał (2011:127) also indicates that the ethical issue of the local media can be a problem pretense local media, in particular, the following phenomena:

(1) "The apparent locality of the discussed issues - are dealt with political issues on the local political systems, but these systems analysis diagram is artificially transferred to the local area from the area of the national (or simply a subject of nationwide local outweighs the subject);

(2) The apparent location of the editorial office - a) the editorial office is not located in the area or b) the editorial office is located in the area but re Presenting non-business interests (eg interests of the corporation to which he belongs);

(3) Apparent activity to integrate local community - Orga low-pressure competitions or local events, which, however, are aimed at diverting attention from the important issues of the community or improve the image of some company or politics;

(4) Apparent political impartiality - through informal agreements The editorial staff, or the journalists themselves, local media can be used as a propaganda tube;

(5) The apparent independence (the material, but also immaterial)

\section{Economic Problems of Local Media}

Gradual computerization of the media space has led to a decline in print media sales and an increase in the quality of electronic media. In the case of radio stations, the saturated type of market is attractive to advertisers, but requires proper formatting of the radio. In the case of regional television, the chance is to place TVP Regional Television on one of the Digital Terrestrial Television multiplexes. However, as with the press, the development of the internet has reduced the local radio's audience and decreased the number of viewers of regional television stations. 
In the case of the printed press is currently (as of June 2014) in the Podkarpackie press market leader is Nowiny newspaper, which according. research noted the circulation of 25,544 copies trade in consolidated ( + subscription sales at the distribution points) at 19 391 (Telescope 2014). Second regional dayli newspaper available in Rzeszów it reached total sales of 9460 at the end of 16013. (Telescope 2014) The Chamber of Press Publishers identifies the following problems and trends for the printed press:

(1) Systematic decline in sales

(2) Decreasing share of the press in the "advertising slice" (that is, total spending on advertising in various media types),

(3) Dynamic changes in people's lifestyles, resulting in disturbances in the natural cycle, supplementing the group of readers through successive,

(4) Progressive digitization of social communication processes, resulting in abandoning the press as a medium of information for various types of digital media, mainly related to the Internet,

(5) Increasing competition volumes and the free press of low quality. (Izba Wydawców Prasy 2014)

In the same document the Chamber of Press Publishers points to the possibility of reversing the above-mentioned trends in limiting the free distribution of content on the Internet and introducing new sales models, such as mobile device editions and ebook readers. Similarly, the problem can be resolved by making available the content of radio and television broadcasts of local and regional radio and television stations In live stream technology through websites and web applications.

\section{Historical Issues of Local Media. Case of Polish Media Market}

Local media form the basis of civil society. Although they are struggling with financial problems, they play an important opinion-forming role, they inform about local issues, the most interesting readers. The local press is very popular among recipients, and electronic media (especially local radio) often have tens of thousands of listeners and viewers.

Until 1989, the local press system in Poland was very poorly developed. The importance of the local press rapidly increased after 1989. The local recipient became extremely valuable - it guaranteed that the press and the media in general would stay on the market (rather than adequate political support). Until the time of changes, general-interest local letters accounted for $1.7 \%$ of all newspapers and magazines in Poland. By the end of 1991, 1426 local newsletters had already been published. Most local magazines were published in the strongly urbanized Upper Silesia (over 300 titles), slightly less in Mazovia, Wielkopolska and Lesser Poland. $77 \%$ of local magazines, however, appeared in circulation not exceeding 2,000 copies. The circulation of more than 10,000 has been obtained and still obtains only about $2 \%$ of the letters. Monthly, bimonthly and quarterly magazines play a dominant role. (Poland... 2004)

Publishing enthusiasm lasted until the end of 1991, later the market calmed down. The new newspapers and magazines that were created spontaneously in Poland proved to be short-term initiatives, in most cases without any chance for continuation. This made journalists and publishers realize how difficult it is to create new media, even when there 
are no political and administrative limitations. (Paulus 2005)

In later years, there were changes in ownership, which consisted primarily of buying up, by foreign capital, subsequent titles. Investing big media corporations have slowly become transnational empires. The regional press is usually of general informative nature and does not constitute direct competition for the local press.

The basis for the functioning of the local press in Poland - according to press studies are the goals and tasks that this press has to meet. Its publisher can be either a legal person or a natural person or an entity that does not have legal personality. After the political transformation, the bodies issuing the local press are natural persons, private and state enterprises, self-government and state authorities of various levels, foundations, trade unions, socio-cultural societies and others. (Bubula 2012) At the same time, it should be remembered that the local press segment is quite unstable, and the potential recipient departs from the readership of the local title with a larger spatial coverage for the magazine dealing with the immediate environment. This process is called "change of scale" by media experts. (

As part of the local press, we distinguish private publishing houses and local government publications (possibly subsidized by self-governments of communes and counties). The activities of the local press can be divided into two specific parts: the first one is information about the current activity of the authorities, while the second is the coverage and promotion of the life of individual local communities. Publishers of local periodicals in publications emphasize a very positive image of social, cultural and economic life. However, they forget about promoting, for example, through mutated pages in the pages of the general regional press, they do not update internet websites, which are the best way to promote them, they sell their magazines in the cheapest way. The problem is also publishing in the pages of local newspapers (especially local government) only very positive articles, as well as a fairly modest way of distribution. Unfortunately, there is a lack of criticism in local government magazines. If it already appears, it is depersonalized, there is no detailed analysis of the economic situation of the commune. However, this is a characteristic situation for most of this type of magazines in Poland. The editors of these types of papers are usually employees of self-government bodies, so it is clear that they will not criticize their employers. Therefore, they focus on a professional graphic layout and typically promotional articles. The functions, goals and tasks of the local press are subordinated to the expectations of recipients, owners, local business (potential advertisers), local authorities and other superior decision-making centers (eg government, regional authorities, hierarchy of churches and denominations). (Miodowski 2002)

In turn, the internal structure of a local magazine depends on the goals and tasks set before the local magazine and the readers' circles. The four basic elements of the local magazine are usually the information part, journalism, artistic and entertainment, utility and advertising. The role of this last link is important. It happens that advertisements are prime materials in local private magazines. It is common to display sensational publications to attract readers. 


\section{Summary}

As was written at PwC raport "The Polish media and entertainment market by 2022 will grow at an average annual rate of $3.5 \%$ and at the end of the period under review its value will amount to USD 13.4 billion, compared to PLN 10.6 billion at the end of 2018. OTT (over the top) OT'T (over the top), ie streaming services delivering film and television content over the Internet, without the need to pay subscription for cable or satellite television (growth rate of 13.3\%) are the segments that will be responsible for this dynamic. and internet advertising (12.5\%)." PwC experts point out that OTT, contrary to earlier predictions, is not replacing traditional television yet, rather it is complementing it and developing in parallel. Despite strong growth, by 2022 this segment will globally account for $26 \%$ of the TV subscription market. In the case of the second, fastest growing area, ie Internet advertising, the average annual development rate will amount to $12.5 \%$, and at the end of the analyzed period its value will reach nearly USD 1.7 billion. compared to 1.1 billion at the end of 2018. Display and paid search advertising remain the largest categories of online advertising in Poland. The use of this format in social media contributed to the strengthening of the display category. Currently, the largest amount of advertising on the network is allocated by companies from the trade, automotive and telecommunications sectors.

\section{References}

Bubula B., (2012), Kto ma media w Polsce, Nasz Dziennik, https://naszdziennik.pl/mysl/2271,kto-mamedia-w-polsce.html

Capurro, R., Hjørland, B. (2003). The concept of information. Annual Review of Information Science and Technology, 37(8), 343-411

Corner, J. (2007) 'Media, power and culture', in E. Devereux (ed.), Media Studies, pp. 211-30. London: Sage.

Kovach B., Rosenstiel T. (2007), The Elements of Journalism: What Newspeople Should Know and the Public Should Expect. London: Three Rivers Press

McChesney R. (2012). "Farewell to Journalism?". Journalism Practice. 6 (5-6): 614-26.

Męcfal S. (2011), Między pozorem a rzeczywistością. Problemy mediów lokalnych, [in:] Pucek Z., Bierówka J., Media a opinie i postawy spoteczne. Kraków: Krakowskie Towarzystwo Edukacyjne - Oficyna Wydawnicza

Midowski A., (2006). Rola prasy w polskim życiu politycznym i wewnętrznej wojnie informacyjnej (grudzień 2002 - październik 2005), http://hdl.handle.net/11320/6140

Paulus B. (2005). Polska prasa w zarysie historycznym od okresu przemian w 1989 roku. https://reporterzy.info/14,polska prasa w zarysie historycznym od okresu przemian w 1989 roku.html

Pokorna-Ignatowicz K. (2001) Problemy zawodowe dziennikarzy w Polsce u progu nowego wieku na podstawie analizy branżowego miesięcznika „Press", Studia Medioznawcze 3/2001.

"Poland: Directory: the Press" (2004). Europa World Year Book. Taylor \& Francis. 2004.

Rogers, E. M. (1976). Communication and Development: The Passing of the Dominant Paradigm. Communication Research, 3(2), 213-24

Shangyuan W., Tandoc E., Salmon Ch. (2018) Journalism Reconfigured. Journalism Studies, pages 1-18.

Teleskop (2014) http://www.teleskop.org.pl/zkdp/index.jsp?p=publicData

Webster, F. (2002) 'The information society revisited', in L. Lievrouw and S. Livingstone (eds), The Handbook of New Media, pp. 443-57. London: Sage. 